CHAPTER 14

\title{
Ceapmenn and Portmenn: Trade, Exchange and the Landscape of Early Medieval Wessex
}

\author{
Alexander Langlands
}

It would seem that the influential views of Henri Pirenne have finally been given a decent funeral. ${ }^{1}$ No attempt here is made, therefore, to exhume the "adventurers," "vagabonds," and those who "seize the many opportunities ... which commercial life offered" by using their "wits to get a living." ${ }^{2}$ But an exploration of the "niches for self-determined action, free market activities, and craft production for unknown consumers," and what Joachim Henning has termed "innovative impulses for town development," is intended to cast light on "the true keepers of the light of the urban economy": the traders and craftsmen who lived in emporia, in wics, in old Roman towns and in all sorts of settlement agglomerations. ${ }^{3}$ The true keepers in this context were the traders and townsmen - the 'chapmen' and 'portmen' - of Anglo-Saxon Wessex and by reconstructing the geography of trade through a central corridor of this outlier of the Frankish economic sphere, the dynamics and developments over time within two major agricultural specialisms — sheep and cattle farming — can be explored to demonstrate that both the industries themselves and those concerned with their successful management exerted a pull that influenced key developments in the political control of the late Saxon economy.

1 Peter Clark, "Editor's Preface," in Adriaan Verhulst, The Rise of Cities in North-West Europe (Cambridge, 1999), pp. vii-viii.

2 Henri Pirenne, Economic and Social History of Medieval Europe, trans. I.E. Clegg (London, 1936), pp. 46-48; Henri Pirenne, Medieval Cities: Their Origins and the Revival of Trade, trans. F.D. Halsey (Princeton, 1969), pp. 114-15.

3 Joachim Henning, "Early European Towns. The Development of the Economy in the Frankish Realm between Dynamism and Deceleration AD 500-1100," in Post-Roman Towns, Trade and Settlement in Europe and Byzantium Vol. 1, the Heirs of the Roman West ed. Joachim Henning (Berlin and New York, 2007), pp. 219-32, at p. 231. 


\section{The 'ceapmanna del'}

In a broadly acceptable charter recording a grant of land at Highclere (Cleran) made by King Eadred to Ælfsige, Bishop of Winchester in 955, the following landmarks are recorded in the boundary clause:

on scip del of scip delle on cyp manna delle. andlang weges eft east on hyldan hlew

to sheep dell, from sheep dell to traders' dell, along the way back east to hyldan tumulus ${ }^{4}$

In its wider landscape setting, the traders' dell sits at a major crossroads within the north Wessex landscape. The location is almost exactly at a mid-point between Oxford and Southampton, and is surrounded by one of the most expansive tracts of open chalk downland in Wessex. Characterised by numerous occurrences of mere (in this case, referring to dew ponds), and bounded by gates and hedges recorded in charters and place-names, this upland is likely to have been an important area of grazing at this time. ${ }^{5}$ The area occupies a natural depression between the ridgeway and a promontory now known as Beacon Hill on which lies a hillfort where evidence of Neolithic, Bronze Age, Iron Age and Roman activity has been recovered. ${ }^{6}$ It sits at the point where the boundaries of the Domesday hundreds of Esseborne (Hurstbourne, later Pastrow), Evingar and Kingsclere meet. ${ }^{7}$ These topographical factors alone would mark out the location as relatively significant but it is the information gleaned from the boundary clauses that illuminates this place as one of important transactions.

$4 \mathrm{~S}_{5} 65$.

5 Alexander J. Langlands, The Ancient Ways of Wessex: Travel and Communication in an Early Medieval Landscape (Oxford, 2019), pp. 80-81, Fig. 19. Buttermere (Butermere in A.D. 863, S 336) is evidence of the herding of cows for dairying purposes but it would seem likely that a policy of mixed grazing of cattle and sheep, one that has an overall benefit to the downland sward, was in operation. See also Harold S.A. Fox, "Butter Place-Names and Transhumance," in A Commodity of Good Names: Essays in Honour of Margaret Gelling, ed. Oliver J. Padel and David N. Parsons (Donington, 2008), pp. 352-64.

6 Bruce Eagles, "A New Survey of the Hillfort on Beacon Hill, Burghclere, Hampshire," PHFCAS 148 (1991), 98-103.

7 William Page, "A History of Evingar," in vcH Hants 4 (London, 1911), p. 273. 
The nature of the landmarks in this area make it relatively easy to place them and O.G.S. Crawford, followed by G.B. Grundy, associates the traders' and sheep 'dells' with a series of valley-head depressions and some (then) upstanding earthworks on the line of the current parish boundary. ${ }^{8}$ This series of landmarks (excluding hounds' hill) is referred to in reverse order in a grant of land including Crux Easton (Eastune) made by King Edgar in 961 to Abingdon Abbey, and the boundary clause for the charter records the following landmarks but with a significant difference:

peet on hyldan hlcew, ponne andlang streates oð ceapmanna del, of ceapmanna dele pcet on portmanna [del], pcet on hunda(n) hylle

thence to hyldan tumulus, then along the street as far as traders' dell, from traders' dell thence to townsmen's dell thence to hounds' hill ${ }^{9}$

An entirely new boundary clause for the Highclere estate was drawn up for Edgar's grant to Ælfwine in 959, where other landmarks of note are:

to weard rode. panone an frangsing cecer. of pam cecere on wic herpað. and lang herpaðes on weard setl

to the look-out/guard clearing, then to the (?)people of Francia's/Franks' field, ${ }^{10}$ from the field to the wic army path, along the army path to the look-out seat ${ }^{11}$

Taking all of these landmarks together, the geography of this area can be reconstructed in some detail (Fig. 14.1). It is safe to assume that the scip element refers to the main order of business. This is a dell into which the hounds, before being retired to hound hill, can herd the sheep so that they can be separated out into constituent flocks for the undertaking of seasonal tasks such as

8 O.G.S. Crawford, The Andover District (Oxford, 1922), pp. 67-68, 72-73, 80; G.B. Grundy, "The Saxon Land Charters of Hampshire with Notes on Place and Field Names," Archaeological Journal 31 (1924), 31-126, at pp. 58-6o.

9 S 689: Susan E. Kelly, ed., Charters of Abingdon Abbey, Part 2 (Oxford, 2001), pp. 364-69, no. 89. See also the translation of the bounds at $<\mathrm{http}$ ://www.langscape.org.uk/descriptions/ glossed/L_689.2_ooo.html> (accessed 1o Dec 2016).

10 A note of caution is needed here but for the combinations ng and nc see, Peter S. Baker, The Anglo-Saxon Chronicle, Volume 8: MS F (Cambridge, 2000), p. xci and for Frangland see s.a. 882. 'Frangland' is also used repeatedly in the Peterborough Manuscript (MS E) s.a. 880,881 and 882 .

$11 \mathrm{~S} 680$. 


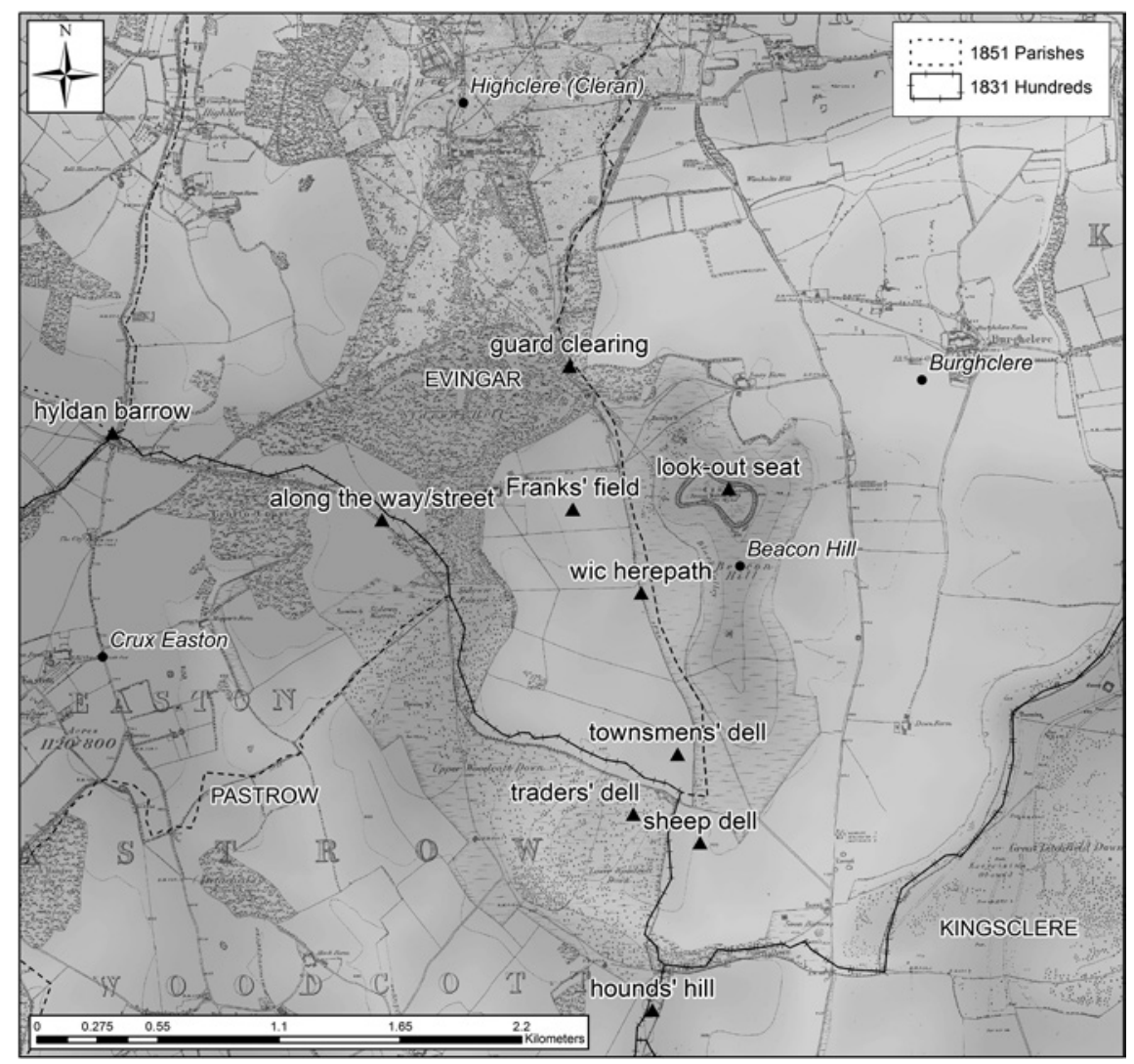

FIGURE 14.1 Selected boundary marks from 1oth-century charters recording grants of land at Highclere and Crux Easton (Contains OS 1st Edition Six Inch base map (C) CROWN COPYRIGHT AND LANDMARK INFORMATION GROUP LIMITED (2018), ALL RIGHTS RESERVED)

ear-clipping, the drafting of lambs from ewes and various transactions involving the traders. At this point it is tempting to consider the possible Franks of the 'frangsing æcer' as here to oversee the purchasing of the finest fleeces in a scene reminiscent of an 11th-century illustrated calendar page for May, where a group of three cloaked individuals look on as shepherd and master consider the condition of a lamb's fleece. ${ }^{12}$ In the sheep dell, all would be enjoying the protection of the guards in the 'weard setl', and upon completion of transaction, the fleeces, still adorning their charges' backs, could then be herded down

12 British Library, Cotton Tiberius B. v, fol. 5r, at <http://www.bl.uk/onlinegallery/onlineex/ illmanus/cottmanucoll/m/oncottibboooo5uoooo500o.html> (accessed 12 Jun. 2018). 
through the 'weard rode' in the direction of a 'sceapwæsce' (sheep wash), ${ }^{13}$ before drying, shearing and transportation along the 'wic herepath' in the direction of the continent, presumably via Southampton. This topographical configuration fits with a body of historical evidence that has established two things: that the trade in wool to the continent provides the best explanation for the growing wealth of silver in Anglo-Saxon England, and that the preeminence of Flanders in the cloth industry in the third quarter of the nth century was dependent on an English wool trade dating back to at least the 1oth. ${ }^{14}$

\section{The 'Portmonna hyðe'}

In a "highly unusual document" King Edgar grants to Abingdon a unique package of possessions and facilities that includes a vineyard at pecet (Watchet, Somerset), royal dues at Suðhamtune (Southampton), the fishing of one ship and the royal toll at both Hpitan clife (?Whitecliff Bay, Isle of Wight) and Portmonna hyðe, and a salt works and one hide at Brunwic wer. ${ }^{15}$ With the exception of Watchet it is reasonable to assume that all of the other locations mentioned are within the immediate sailing orbit of Southampton (Fig. 14.2).16 Given the likely pattern of exploitation in the New Forest, we can safely assume the reason for the presence of the townsmen at Hythe: in a study of the boundary clauses for North and South Stoneham, Bishopstoke and Durley, Christopher Currie posited a system of wood pasturage for cattle similar to that operating in the New Forest as recently as the 19th century. ${ }^{17}$ He identified droveways linking these areas to Southampton and further suggested that the same arrangements were likely to have been in existence in the New Forest. ${ }^{18}$ Presumably the 'Portmonna hyðe' represented a short cut, a means by which 'store cattle' could be traded without the arduous and potentially conditionsapping drove, or hazardous ferry trip, to Southampton or Winchester. This

\footnotetext{
13 Another landmark from S 680, located a short distance north of Highclere in Fig. 14.1.

14 Edward Miller and John Hatcher, Medieval England: Towns, Commerce and Crafts 10861348 (London, 1995), p. 16; P.H. Sawyer, "The Wealth of England in the Eleventh Century," TRHS 5th ser., 15 (1965), 145-64, at pp. 16o-64.

15 S 701; Kelly, ed., Charters of Abingdon Abbey, pp. 377-81, no. 93.

16 For a discussion on the likely locations of all of these places see Kelly, ed., Charters of Abingdon Abbey, pp. 379-81. The wer (weir) of Brunwic may very well survive preserved in the dam of Brownwich pond (O.S. SU 5190203748 ).

17 Christopher K. Currie, "Saxon Charters and Landscape Evolution in the South-Central Hampshire Basin," PHFCAS 50 (1995), 103-25, at pp. 115-18.

18 Currie, "Saxon Charters and Landscape Evolution," pp. 116-17.
} 


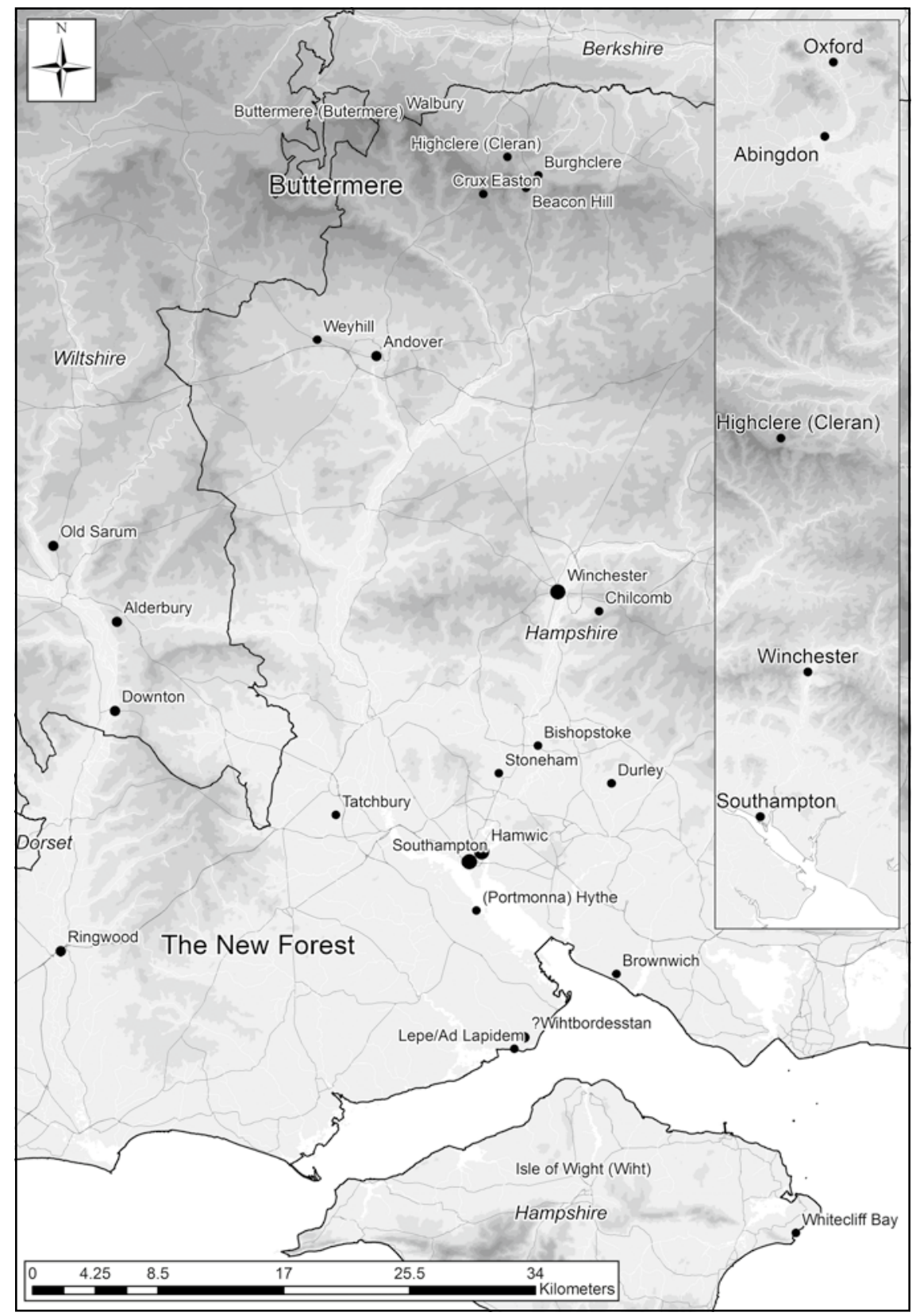

FIGURE 14.2 Places mentioned in the text including (inset) the Oxford to Southampton trade corridor 
geographical configuration, one where witnesses are brought to the cattle rather than the other way round, finds parallels in Edgar's law-code promulgated at Wihtbordesstan. Apparently issued in the aftermath of a widespread pestilence, it is chiefly celebrated as a text directed towards the Danelaw but displays a "clarity of detail in the regularization of cattle-trading that was largely absent from what had gone before." 19

The location of Wihtbordesstan is unknown. Patrick Wormald suggested a stone "presumably named from a person of repute" and made a tentative connection with Wihtbrord (a thegn of Alfred and Edward the Elder) who received Fovant and was involved in the Helmstan affair. ${ }^{20}$ Stones with associated personal names are occasionally used as hundred meeting-places, are a frequent occurrence in Anglo-Saxon charter bounds and the name Wihtbrord itself would be a perfectly acceptable place-name element in this part of AngloSaxon England. Yet, whilst there is much that weighs in favour of the traditional interpretation, an alternative interpretation of the place and a connection with the New Forest is offered here. Taking piht for the Isle of Wight, and the bord element to indicate a border (as in hem, edge, or coast), ${ }^{21}$ a literal reading gives 'the stone on the Isle of Wight (facing) seaboard'. On the bord element, there is a sense of seashore or 'coastal border' emerging in the late Saxon period in relation to sea-going vessels, with the possibility that bord-stcep can be related to 'seashore' whilst baec-bord appears to refer to the nautical terms 'larboard' and 'port (side).' ${ }^{22}$ Both of these uses might, at least, support a coastal location, and it is clear in Alfred's use of innanbordes and ütonbordes that being inside or outside of the border-or coast-is an indication of whether one is at 'home' or 'abroad'.23 All of this points to Stone Point and nearby Lepe (derived from the Latin lapis), on the southern coast of the New

19 Patrick Wormald, The Making of English Law: King Alfred to the Twelfth Century (Oxford, 1999), pp. 317-20.

$20 \quad S_{364}$; 1445; Wormald, The Making of English Law, p. 442., n. 92.

21 "board, n.". oed Online. June 2018. Oxford University Press. http://www.oed.com/view/ Entry/20731? [accessed 12/06/2018].

22 For bord-stcep, (Andreas, line 442), G.P. Krapp, The Vercelli Book (New York, 1932), pp. 15, 110 has 'the rigging of a ship', although for 'seashore' see, for example, S.A.J. Bradley, ed. and trans., Anglo-Saxon Poetry (London, 1982), p. 122 and The Dictionary of Old English: A to H, tapor.library.utoronto.ca/doe/ [accessed 12/06/2018]. In the most recent edition of Andreas, however, the term is translated as 'ship's walls', Richard North and Michael Bintley, eds., Andreas: An Edition (Liverpool, 2016), p. 141. The use here is considered to be ironic in its contrasting of the instability of the vessel with the stability of a safe harbour, Michael Bintley, pers. comm. 2018.

23 For 'home' and 'abroad' see Carole Hough and John Corbett, Beginning Old English, and ed. (Basingstoke, 2013), pp. 134-36; Simon Keynes and Michael Lapidge, Alfred the Great: Asser's Life of King Alfred and Other Contemporary Sources (Harmondsworth, 1983), pp. 124-25. 
Forest, representing a reasonably strong candidate for the location of the promulgation of IV Edgar.

There is certainly sense in the location for an assembly of this importance. In the first instance, it is well connected. There was a Roman road which ran from Tatchbury in a south-easterly direction towards Stone Point, linking it in to a proposed network of roads in this area that connected Southampton, Winchester, Ringwood (Hants), Downton and Old Sarum (Wilts.). ${ }^{24}$ It seems reasonable to presume, as proposed by Ivan Margary, that somewhere in the immediate vicinity of Stone Point there was a Roman quayside and one that may still have been functioning as a stcep into the early medieval period. Bede tells us that during Cædwalla's mid-68os purge of the Isle of Wight, an "island entirely given up to idolatry," two young princes fled the violence, crossing over into the neighbouring realm of the Jutes. They were taken, we are told, to a place called Ad Lapidem (at Stone) from where, ultimately, they were betrayed and condemned to death. ${ }^{25}$ Stone Point is accepted as the location for Ad Lapi$\mathrm{dem}$, and clearly a place at which important decisions were made. ${ }^{26}$

\section{Laws, Politics and the Economy of Mid-1oth-century Wessex}

Both of these case studies conform to the observation that the evidence of King Edgar's legislation is complemented by the evidence of his charters. ${ }^{27}$ If the hypothetical location of Wihtbordesstan in the New Forest makes some sense of the relative importance of cattle trading in the code itself and gives a rationale for the townsmen being at Hythe, then the same can be said of Edgar's law code promulgated at Andover where the livestock of concern is sheep. Considered "the most thoughtfully crafted Anglo-Saxon law-making to date," it contains very precise provisions for the sale of wool and although these sit at the end of the code, the secular part of which is chiefly concerned with justice, court attendance and surety, they are grouped within a chapter that also contains the clause "And one coinage is to be current throughout all the king's

24 Ivan D. Margary, Roman Roads in Britain, 3rd ed. (London, 1973), pp. 94-96; A. Clarke, "The Roman Road on the Eastern Fringe of the New Forest, from Shorn Hill to Lepe," PHFCAS $58(2003), 33-58$.

25 Bede $H E$ IV.16.

26 Barbara A.E. Yorke, Wessex in the Early Middle Ages (Leicester, 1995), pp. 90, n. 56; J.M. Wallace-Hadrill, Bede's Ecclesiastical History of the English People: A Historical Commentary (Oxford, 1988), pp. 156-57; J.E.B. Gover, Hampshire Place-Names (Unpublished manuscript, Hampshire Records Office, 1961), pp. 41, 199.

27 Simon Keynes, "Edgar, Rex Admirabilis," in Edgar, King of the English 959-975, ed. Donald Scragg (Woodbridge, 2008), p. 12. 
dominion, and no man is to refuse it." ${ }^{28}$ The link between coinage, revenue and wool is made explicit in the Andover code in what Simon Keynes calls "basic commercial controls. ${ }^{29}$

These commercial controls are exemplified in the 973/4 coinage reform of Edgar's reign, which demonstrated a monetary system of great sophistication. ${ }^{30}$ It was a system that had been used to great effect by Carolingian rulers in the mid-gth century, one that was enforced by a new administrative framework where all coins throughout the kingdom were struck to a uniform design and one that wasto go on and prove, in thelong run, "nothing short of revolutionary."31 These monetary reforms produced the coinage of a newly-regulated order and other elements of the Andover code (as well as the Hundred Ordinance) reflect a period within which order is being imposed on the less formal and less uniform arrangements of the earlier 1oth century. ${ }^{32}$

Yet, whilst Edgar appears to have been regularising trade and tightening the fiscal grip on the economy, he was clearly loosening the grip in other areas. We see this most visibly in the laws relating to the control and policing of transactions. Although Edward the Elder's laws are clear about the restriction of trade to boroughs, Richard Hodges argues that royal concern had to be "realistic" about trading, and Æthelstan clearly strikes a more conciliatory note in stipulating that only larger transactions were legally obliged to take place within the burhs. ${ }^{33}$ Edgar goes one step further at Wihtbordesstan. Every man was to be under surety in and outside the boroughs, and witnesses are to be appointed to oversee the buying and selling of goods, in either borough or wapentake. However, if one were to ride out to make a purchase, the obligation is there to inform neighbours before and on return of witnessed transactions. The conciliatory tone is at its most understanding of the nature of trade when it recognises

28 III Edgar 8.2, 8.3; EHD 1, p. 433; Wormald, The Making of English Law: King Alfred to the Twelfth Century, p. 317 .

29 Keynes, "Edgar, Rex Admirabilis," p. 11.

3o James Campbell, "Observations on English Government from the Tenth to the Twelfth Century," TRHS 5th ser., 25 (1975), 39-54 at pp. 39-40; James L. Bolton, Money in the Medieval English Economy: 973-1489 (Manchester, 2012), pp. 88-89.

31 Simon Coupland, "Money and Coinage under Louis the Pious," Francia 17:1 (1990), 22-54; R.H.M. Dolley and D.M. Metcalf, "The Reform of the English Coinage under Eadgar," in Anglo-Saxon Coins, ed. R.H.M. Dolley (London, 1961), pp. 136-68; Rory Naismith, "Prelude to Reform: Tenth-Century Coinage in Perspective," in Early Medieval Monetary History: Studies in Memory of Mark Blackburn, ed. Rory Naismith, Martin Allen, and Elina Screen (Farnham, 2014), pp. 39-83, at p. 82.

32 Keynes, "Edgar, Rex Admirabilis," pp. 11, 23.

33 Richard Hodges, Dark Age Economics: The Origins of Towns and Trade, A.D. 6oo-10oo (London, 1982), p. 165 . 
that one can "unexpectedly" (unmyndlunge) make a purchase when out on any journey but that one must have the cattle presented to the township (tunscipe) on the common pasture upon return. In this clause it is explicit that it is on cattle that the emphasis is placed and the following clauses all deal with permutations that arise in the witnessing of cattle transactions, outside of the boroughs. These clauses, from both codes, provide a legal context for the presence of townsmen at Hythe, on the edge of a very important cattle-pasturing common, and at Burghclere, on the edge of an extensive area of downland sheep grazing.

There is clearly some joined-up thinking between the regulation of both the sheep and cattle trade in Edgar's law codes, his reform of the coinage and his granting of land in key areas to Abingdon, his institutional ally in these endeavours. Questions emerge, however, as to whether his actions can be seen as a response to a relatively recent boom in livestock trading or whether, in fact, this represents a pioneering campaign to expand the interests of the nascent Anglo-Saxon state into an already burgeoning industry in order to harness the wealth of the trade in livestock in the countryside and beyond the burhs. Some support for the latter hypothesis comes in the form of a growing body of evidence for exchange beyond the wics in the 8th century, to which attention will now be turned. ${ }^{34}$

\section{Sheep and Cattle in the Age of Emporia}

The widespread production of high-quality woven goods in the middle AngloSaxon economy is reflected in the relatively high price they command in Ine's law code and the prevalence in the archaeological evidence from the period of loom weights and spindle whorls. ${ }^{35}$ That these goods, in the form of blankets or cloaks, figured as a traded commodity between Anglo-Saxon England and

34 Katharina Ulmschneider and Tim Pestell, "Introduction: Early Medieval Markets and 'Productive' Sites," and Ben Palmer, "The Hinterlands of Three Southern English Emporia: Some Common Themes," in Markets in Medieval Europe: Trading and 'Productive' Sites, 650-850, ed. Katharina Ulmschneider and Tim Pestell (Macclesfield, 2003), pp. 1-11 and pp. 48-6o; Chris Scull, "Urban Centres in Pre-Viking England," in The Anglo-Saxons from the Migration Period to the Eighth Century, ed. John Hines (Woodbridge, 1997), pp. 269-98; Michael D. Costen and Nicholas P. Costen, "Trade and Exchange in Anglo-Saxon Wessex, c. AD 600-780," Medieval Archaeology, 6o:1 (2016), 1-26.

35 Ine 55, 69, in Die Gesetze Der Angelsachen, ed. Felix Liebermann, 3 vols (Halle, 1903-1916), 1:114, 118; John R. Maddicott, "Prosperity, Power and the Age of Bede and Beowulf," Proceedings of the British Academy 117 (2002), 49-71, at p. 72. 
Frankish territories is established historically from at least the reign of King Offa. ${ }^{36}$ In a recent analysis of coin finds of the late 7 th to mid-gth centuries, a lively trade in West Wessex has been proposed suggesting a strong 'Frisian' connection where the most likely commodity is wool or woollen textiles. ${ }^{37}$ The Franks of the frang sing acer may need to remain hypothetical, but it is incumbent on us to consider who, in Alfred's laws, are the 'men' that the traders (ciepmonna) are required to take before the king's reeve before making their way 'up' inland and similar stipulations are also found in Ine's code $(688 \times 694)$ where traders are required, if they make their way uppe on londe, to do their business in the presence of witnesses. ${ }^{38}$ If the numismatic evidence does suggest a coin-carrying contingent of Frisian merchants in the 8th century, is this role being fulfilled by Frankish operatives in the 1oth? Is it even a spurious endeavour to differentiate between the two given that, at a later date, the term 'Frisian' seems to be synonymous with 'trader' and it is clear that many of these may even have been Franks?39

The 'traders' dell' and the overshadowing hill-fort at Burghclere may mark a location that had experienced many years of sheep trading. Topographically, it fits a pattern observed for Dorchester, Warminster and Westbury (with their associated hill-forts and tracts of open downland), where coin finds from the middle Anglo-Saxon period suggest important nodes in the wool trade. ${ }^{40} \mathrm{We}$ may not have the numismatic evidence to back this up but there are sceattas recovered from the hill-fort at Walbury (around $10 \mathrm{~km}$ to the west), and on the southern edge of this stretch of downland six coins dated to the 8th and first half of the 9th centuries have been recorded with the find-spot 'Andover'.41 Weyhill (to the immediate west of Andover) stands out as an important place

36 H.R. Loyn, Anglo-Saxon England and the Norman Conquest (London, 1962), pp. 195-96; Joanna Story, Carolingian Connections: Anglo-Saxon England and Carolingian Francia, c. 750-870 (Aldershot, 2003), pp. 195-96.

37 Costen and Costen, "Trade and Exchange in Anglo-Saxon Wessex," p. 22.

38 Alf. 34; Ine. 25; Liebermann, Gesetze, 1:68, 100.

39 Stéphane Lebecq, "On the Use of the Word 'Frisian' in the 6th-1oth Centuries Written Sources: Some Interpretations," in Maritime Celts, Frisians and Saxons, ed. Sean McGrail, СBA Research Report 71 (London, 1990), pp. 85-90; Lebecq, "Routes of Change: Production, and Distribution in the West (5th-8th Century)," in The Transformation of the Roman World AD 40o-9oo, ed. Leslie Webster and Michelle Brown (London, 1997), pp. 67-78, at p. 75 .

$40 \quad$ Costen and Costen, "Trade and Exchange in Anglo-Saxon Wessex," p. 18.

41 Katharina Ulmschneider, Markets, Minsters and Metal-Detectors: The Archaeology of Middle Saxon Lincolnshire and Hampshire Compared, BAR Brit. Ser., 307 (Oxford, 2000), p. 100; Early Medieval Corpus of Coin Finds <http://www-cm.fitzmuseum.cam.ac.uk/emc/> (accessed 22nd Mar. 2016). 
in the history of the sheep farming industry of Southern England. When it is first recorded in the 16th century, it was one of the largest in England, with sheep making up the main commodity of trade. ${ }^{42}$ This economic vibrancy is also reflected in an earlier period. Extremely high quantities of Roman coinage have been reported to the Portable Antiquities Scheme from the parishes surrounding Weyhill and along the course of the Harroway for a distance of $5 \mathrm{~km}$ to the west. ${ }^{43}$ Weyhill is believed to be derived from wēoh meaning 'holy place, heathen temple', and on such a major thoroughfare an area of mass congregation is suggested. ${ }^{44}$ That sheep were a popular source of income here is clear from archaeological excavations of early Saxon-period sites. Against a faunal backdrop where cattle bones outnumber those of sheep on a majority of settlement sites throughout the Anglo-Saxon period, ${ }^{45}$ sites at Chalton, east Hampshire, and Old Down Farm, Andover, buck the trend in that both record higher levels of sheep bones than any other species. ${ }^{46}$

The presence of all major body parts in the cattle faunal assemblages from Hamwic suggests that beasts were being brought in on the hoof and whilst similar circumstances are observed for Ribe and Dorestad, like Jorvik, the assemblages at Hamwic contained a higher percentage of mature beasts. ${ }^{47}$ This has been seen by some to reflect a redistributive economy and one where residents did not have access to markets because, given the choice, people would have purchased younger beasts for consumption. ${ }^{48}$ We are reminded, however, that secondary products often seem to have been just as important in the

42 William Page, "Weyhill with Penton Grafton," in vcH Hants 4, pp. 396-98.

43 The British Museum, Portable Antiquities Scheme <http:www.finds.org.uk> (accessed 22 Jan. 2017).

$44 \quad D E P N$, p. 510.

45 Naomi Sykes, "From $\mathrm{Cu}$ and Sceap to Beffe and Motton: The Management, Distribution, and Consumption of Cattle and Sheep in Medieval England," in Food in Medieval England: Diet and Nutrition, ed. Christopher M. Woolgar, Dale Serjeantson and Tony Waldron (Oxford, 2006), pp. 56-71, at p. $5^{8}$ and fig. 5.1.

46 Peter V. Addyman, David Leigh, and Michael J. Hughes, "Anglo-Saxon Houses at Chalton, Hampshire," Medieval Archaeology 16 (1972), 13-33, at p. 31; Susan M. Davies, "Excavations at Old Down Farm, Andover, Part 1: Saxon," PHFCAS 36 (1980), 161-80, at p. 177.

47 Helena Hamerow, "Agrarian Production and the Emporia of Mid Saxon England, c. AD 650-850," in Post-Roman Towns, Trade and Settlement in Europe and Byzantium Vol. 1, the Heirs of the Roman West ed. Joachim Henning (Berlin; New York, 2007), pp. 219-32, at pp. 220-21.

48 Tom Saunders, "Early Medieval Emporia and the Tributary Social Function," in Wics: The Early Medieval Trading Centres of Northern Europe, ed. David Hill and Robert Cowie (Sheffield, 2001), pp. 7-13; Jennifer Bourdillon, "Countryside and Town: The Animal Resources of Saxon Southampton," in Anglo-Saxon Settlements, ed. Della Hooke (Oxford, 1988), pp. $176-95$, at pp. $188-91$. 
agrarian economy of Anglo-Saxon England and that it may be, for the butchers of Hamwic, that leather was their primary concern. ${ }^{49}$ The assemblages of sheep bones recovered from Hamwic provide a useful parallel in that they suggest wether flocks-older beasts - where wool had been the primary concern. ${ }^{50}$ Although no evidence for leather-working has been discovered at Hamwic, it has been proposed as an export commodity for Wessex's key emporium on the basis of the importance of cattle in the animal bone assemblage alone. ${ }^{51}$ Leather was undoubtedly a key commodity in Anglo-Saxon England with Ælfric's shoewright providing only a cursory list before asserting that "not one of you would want to go through the winter without my craft." ${ }^{2}$ In the 8th century we might assume a relatively high demand for leather of all grades in the emergence of a greater market for protective wear, to say nothing of the role leather would have played as a liquid retainer in itinerant and predominantly aceramic sections of society (e.g. traders, herdsmen, carters, carriers, labourers). For Hamwic, as well, there exists the very real possibility that engagement in vibrant cross-Channel trade required the building and maintenance of fleets of cargo ships that may have employed leather in their sails. ${ }^{53}$ Intensification in crop husbandry from the middle Anglo-Saxon period would have created a greater need for harnessing leather both for the cart and the plough. ${ }^{54}$ Hamwic's butchers may, therefore, have had an active interest in buying older beasts, with more weathered skins, where they required tougher

49 See Debby Banham and Rosamond Faith, Anglo-Saxon Farms and Farming (Oxford, 2014), p. 136 for the importance of secondary products, although no discussion on the production of leather and its importance to the agrarian economy is given.

5o Bourdillon, "Countryside and Town," p. 182.

51 Mark Brisbane, "Hamwic (Saxon Southampton): An 8th-Century Port and Production Centre," in The Rebirth of Towns in the West AD 700-1050, ed. Richard Hodges and Brian Hobley (London, 1988), p. 117; Alan Vince, "Saxon Urban Economies: An Archaeological Perspective," in Environment and Economy in Anglo-Saxon England, ed. James Rackham (York, 1994), pp. 108-19.

52 Elfric's Colloquy, in Anglo-Saxon Prose, ed. and trans. Michael Swanton, rev. ed. (London, 1993), p. 173: "I buy hides and skins and by my craft prepare them, and I make them into various kinds of footwear, slippers and shoes, leggings and leather bottles, reins and trappings, flasks and leather vessels, spur straps and halters, bags and pouches. And not one of you would want to go through the winter without my craft."

53 See Sean McGrail, "Boats and Boatmanship in the Late Prehistoric Southern North Sea and Channel Region," in Maritime Celts, Frisians and Saxons, ed. Sean McGrail, свA Research Report 71(London, 1990), pp. 32-48, for the evidence for leather sails in the late Iron Age.

54 Mark McKerracher, Farming Transformed in Anglo-Saxon England (Oxford, 2018), p. 93. Banham and Faith, Anglo-Saxon Farms and Farming, pp. 294-95. 
and thicker hide to work and as such, may have been enfranchised to purchase beasts of their own choice, to suit their own needs, in a market-based system of exchange. But would they have been purchasing their materials from the herdsmen of the New Forest, or would the herdsmen of the proposed wood pasturage at North and South Stoneham, Bishopstoke and Durley have produced enough to meet their needs?

\section{Discussion}

This paper has been offered in the spirit of Barbara Yorke's more recent collaborations, the Leverhulme Trust-funded Landscapes of Governance and Travel and Communication in Anglo-Saxon England projects, both run from UCL. ${ }^{55}$ A key methodology of these projects is the application of the landscape' paradigm or, more generically, the application of spatial analysis to a diverse evidence base, the constituent parts of which can come with their own specialisms, methodologies and epistemologies. 'Landscape' can serve as a means of integration: a medium that supports and facilitates interdisciplinary scholarship and one that allows for the examination of the spatial dynamics between objects, events and place-names in order to yield new understandings of the past. As an example, the geography of Abingdon's endowments provides an extra dimension to the rationale behind the re-foundation of an important minster site as a new religious powerhouse. It has already been observed that the location of the abbey was very likely dependent on an existing trade route, ${ }^{56}$ but holdings at key nodal points on this main arterial trade route through Wessex, and in places with footholds in the livestock economy, also indicate a clear provisioning strategy along with access to lucrative trading opportunities.

Portman is a relatively rare noun in Old English and in the corpus of surviving examples, links with Edgar are strong. The examples discussed above sit in close proximity to each other in terms of provenance and likely authorship.

55 UCL, Landscapes of Governance, at <http://www.ucl.ac.uk/archaeology/research/projects/assembly>; Travel and Communication in Anglo-Saxon England, <http://www.ucl. ac.uk/archaeology/research/directory/travel-communication-anglo-saxon-england $>$ (accessed 20 Oct. 2017).

56 Alexander Rumble, "Hamtun Alias Hamwic (Saxon Southampton): The Place-Name Traditions and Their Significance," in Excavations at Melbourne Street, Southampton, 1971-6, ed. P. Holdsworth (York, 1980), p. 13. 
They appear in charters that are a year apart and in one manuscript copy, one charter immediately precedes the other, suggesting that at the time of both grants, the concept of townsmen presiding over rural livestock exchanges had currency amongst the agents of Edgar's inner circle. ${ }^{57}$ Portmen also feature in Edgar's renewal of the privileges of Chilcomb granted to Old Minster, Winchester, in a charter that, although spurious in its surviving form, may have a basis in an earlier cartulary, perhaps compiled under the influences of Æthelwold. ${ }^{58}$ Of most interest, however, are the "details of contemporary relevance" in the Old English Legend of the Seven Sleepers. In a text that is, in places, pre-occupied with the business of transactions and specifics of exchange, we find a reference to portmen and sections concerned with recoinages and the debasement of the silver content, the latter of which indicates a date of translation after which Edgar had introduced the practice in $c .973 .{ }^{59}$ The reference to the gift of royal tribute in the package of possessions that includes Portmonna Нyðe is explicit, but can we assume the same gift for the Portmanna dell? Of the powers enjoyed from the New Forest trade, it should also be noted that Abingdon's holdings include Ringwood, again, courtesy of Edgar. ${ }^{60}$ With a derivation from rimuc and wuda, suggesting 'border-wood', this estate commands the main crossing of the Avon from Dorset and beyond and therefore represents another exit point, like Hythe and Lepe, from the New Forest. ${ }^{61}$ These spatial dynamics provide a fresh take on the practicalities of how these grants could be made to work as sources of revenue in order to fund Edgar's ideological ambitions for Abingdon, the "engine-house for Æthelwold's personal crusade of reform." 62

The case-studies offered here further our understanding of developments in the early medieval economy of 1oth-century Wessex, and Europe. It had been customary in the second half of the 9th century in north-west Europe for portus to be used more generally to refer to a trading settlement (rather than the limited sense of mooring place for ships) but unlike cyping and ceapman, port only appears to have been more widely used in Anglo-Saxon England from the

57 Kelly, ed., Charters of Abingdon Abbey, Part 2, no. 89 (S 689); no. 93 (S 701).

58 Alexander Rumble, Property and Piety in Early Medieval Winchester: Documents Relating to the Topography of the Anglo-Saxon and Norman City and Its Minsters, Winchester Studies 4.3 (Oxford, 2002), p. 17.

59 Catherine Cubitt, "'As the Lawbook Teaches': Reeves, Lawbooks and Urban Life in the Anonymous Old English Legend of the Seven Sleepers," EHR 124 (2009), 1021-49, at pp. $1023,1026$.

6o Kelly, ed., Charters of Abingdon Abbey, Part 2, p. 138. no. 87 (S 69o).

61 Richard Coates, The Place-Names of Hampshire (London, 1989), p. 138.

62 Susan E. Kelly, ed., Charters of Abingdon Abbey, Part 1 (Oxford, 200o), p. xl. 
10th century. ${ }^{63}$ It is the laws of the early 1oth century that explicitly restrict trade to the ports that are the clearest indication we have that royal authority may be attempting to replicate an urban model that appears to have been working in 9th-century Francia. ${ }^{64} \mathrm{~A}$ broader consideration of the port placename element in its landscape context may go some way to characterising these developments and where it occurs in conjunction with the ceap element may be even more instructive. ${ }^{65}$ The presence of ceapmanna in the 7 th century is legally attested and that they are involved with inland trade, as opposed to being restricted to bases in the coastal emporia, is clear from their requirement to travel uppe on londe. This orbit of movement finds support in the distribution of chapman- place-names in Wessex and beyond, a review of which indicates a clear association with proposed trade routes of the middle Anglo-Saxon period. ${ }^{66}$ Elsewhere, urban development models based on the strength of terminological data-in particular the relationship between vicus and portushave been proposed for "the most important stage in early medieval development"; the transition from a estate-centred phase in exchange and agriculture to a "wider and free phase conducted by independent merchants and workers who traded or practiced a trade for a profit." 67

The point here is that the ceapmenn and their activity appear to be an existing configuration in the landscape of sheep and cattle farming into which the portus project is being initiated - that the trade of the 9th to 1oth centuries is shaping the design of political economic stimuli rather than the other way round, in contrast to the "false dawn of the age of emporia." 68 For Anglo-Saxon England, law codes, charters and chronicles-as well as archaeological evidence of urban planning - have all, in the past, contributed to a narrative that implicitly views the actions of kings, churches, elites and perhaps the 'state' as instrumental in the advancement of economic ambition in a model where

63 Adriaan Verhulst, The Rise of Cities in North-West Europe (Cambridge, 1999), pp. 48-52; P.H. Sawyer, "Fairs and Markets in Early Medieval England," in Danish Medieval History: New Currents, ed. N. Skyum-Nielsen and Niels Lund (Copenhagen, 1981), pp. 153-68, at pp. $15^{8-62 .}$

64 I Edward 1; II Ethelstan 12, 13.1, in F.L. Attenborough, ed. The Laws of the Earliest English Kings (Cambridge, 1922), pp. 114-15, 134-35; Grenville Astill, "Exchange, Coinage and the Economy of Early Medieval England," in Scale and Scale Change in the Early Middle Ages, ed. Julio Escalona and Andrew Reynolds (Turnhout, 2011), pp. 253-72, at pp. 266-67.

65 E.g. 'Cheapside' in Langport (Somerset), 'Cheap Street' and 'Port R[...] Close' in Bedwyn (Tithe Award, 1850), portmanna land and hrypera ceap Canterbury (Kent, S 905), Binneport (c. 1261) and chupyncliue (1289) in Shaftesbury (Dorset).

66 Langlands, The Ancient Ways of Wessex, pp. 188-191, Fig. 51.

67 Verhulst, The Rise of Cities in North-West Europe, p. 56.

68 Henning, "Early European Towns," p. 31. 
urbanism - the town and the city — are seen as the key formative elements. ${ }^{69}$ Yet, what is conveyed from the reconstruction of the geography of both study areas is clear evidence of a compromise, certainly in topographical terms, within two major elements of the early medieval economy in Wessex. Both sheep and cattle farming, and those concerned with their successful management, exerted a pull that influenced key developments in the political control of the late Saxon economy. Edgar's strategies should therefore be viewed as much as responses as they are initiatives in an on-going negotiation. The restrictions on limiting trade to the burhs may have been lifted, and the need for the witnesses to follow the trade, rather than the other way round, may have been conceded, but elsewhere, in the reform of the coinage, we see a tightening up of fiscal arrangements. It may be apposite, therefore, to extend Rory Naismith's observations on Edgar's reform of the coinage more broadly to the dynamics of the economy of this period: this was a change of tune and conductor, rather than a change of orchestra. ${ }^{70}$

In all of this, what emerges is a paradigm that places more emphasis on the wider constraints of landscape as a variable in the development of the economy and its relationship with ideas of kingship. In the early medieval west social and economic processes can be seen to transcend our traditional periodic division of the past and patterns of trade and external contacts can be seen to extend from prehistory through to the 6th to 7 th centuries and beyond. ${ }^{71} \mathrm{We}$ may do well to extend this line of enquiry to early medieval Wessex and its relationship with its neighbours across the channel. Most recently, Michael and Nicholas Costen have identified "a much older pattern of trading places based not in major royal burhs, but at rural centres, including hill-forts," a reiteration of the assertion made by Grenville Astill that the social and economic relationships of the majority of the population were determined by an older, pre-burh

69 See H.R. Loyn, "Towns in Late Anglo-Saxon England: The Evidence and Some Possible Lines of Enquiry," in England before the Conquest: Studies in Primary Sources Presented to Dorothy Whitelock, ed. Peter Clemoes and Kathleen Hughes (Cambridge, 1971), pp. 115-28, at pp. 128, for towns as the 'supreme' achievement of Alfred, Edward and their successors; also, Martin Biddle and David Hill, "Late Saxon Planned Towns," AntJ 51 (1971), 70-85; Susan Reynolds, An Introduction to the History of Medieval Towns (Oxford, 1977), pp. 34-36.

$70 \quad$ Naismith, "Prelude to Reform: Tenth-Century Coinage in Perspective," p. 82.

71 Barry Cunliffe, Facing the Ocean: The Atlantic and Its Peoples (Oxford, 2001), especially ch. 13, "The Longue Durée," pp. 554-67; David Griffiths, "Markets and Productive Sites: A View from Western Britain," in Markets in Medieval Europe: Trading and 'Productive' Sites, 650850, ed. Katharina Ulmschneider and Tim Pestell (Macclesfield, 2003), p. 72. 
pattern of trading. ${ }^{72}$ This pattern of trading ultimately has its roots in the landscapes that produce the items of commerce and as such invites us to augment the role of the agents that plied their trade on a daily basis within these worlds. Landscape therefore becomes the document through which we access and give voice to the people; the waves of the tides on the crest of which sits the froth of political action. ${ }^{73}$

72 Costen and Costen, "Trade and Exchange in Anglo-Saxon Wessex, " p. 23; Grenville Astill, "Community, Identity and the Case of the Late Anglo-Saxon Town: The Case of Southern England," in People and Space in the Early Middle Ages, AD 300-1300, ed. Wendy Davies, Guy Halsall, and Andrew J. Reynolds (Turnhout, 2006), pp. 253-72, at p. 254.

73 I am hugely grateful to Ryan Lavelle and an anonymous reader for generously giving up their time to read and comment on earlier drafts of this paper. John Baker very kindly offered advice on the place-names discussed. I consider myself very lukcy to have met Barbara Yorke at a time in my life when I was looking for guidance and direction in following my passion for the study of the early medieval past. For her support during critical milestones in my career, I shall remain eternally grateful. 